Eixo temático: 3. Mediação Teatral e Metodologias de Ensino

\title{
Reflexão e emancipação intelectual na criação teatral de estudantes do Ensino Médio
}

\section{Resumo}

A investigação apresenta um processo de criação teatral realizado com alunos do Ensino Médio Integrado do Instituto Federal de Educação, Ciência e Tecnologia (IFSP), no Câmpus Boituva, a partir da questão “O que você preferiria não, na escola?”, uma apropriação do conto "Bartleby, o escrivão”, de Herman Melville (2005). Para tanto, utiliza a metodologia de “jogos com textos” de Koudela (1999) e Pupo (2005) e conversas não-diretivas como coleta de dados. A pesquisa se vale de relatos sobre o cotidiano escolar dos estudantes, no intuito de propiciar a reflexão da escola, na situação de criação, em uma lógica de emancipação intelectual, com Rancière (2011). Os dados coletados denotam que a liberdade de criação que o “jogo com texto” propicia, favorece a prática reflexiva do ambiente escolar.

Palavras-chave: Criação Teatral. Reflexão. Emancipação Intelectual.

\section{Résumé}

La recherche présente un processus de création théâtrale réalisé avec des étudiants du Lycée Intégré de l'Institut Fédéral de l'Education, des Sciences et de la Technologie (IFSP), au campus Boituva, de la question "Que préféreriez-vous pas, à l'école?", du conte "Bartleby, l'écrivain", par Herman Melville (2005). Pour ce faire, la recherche utilise la méthodologie «jeux avec textes» de Koudela (1999) et Pupo (2005) et des conversations non-directives comme collecte de données. La recherche s'appuie sur des rapports sur la vie scolaire quotidienne des élèves, afin de favoriser la réflexion de l'école, dans la situation de la création, dans une logique d'émancipation intellectuelle, avec Rancière (2011). Les données recueillies indiquent que la liberté de création que le «jeu avec texte» permet, favorise la pratique réflexive de l'environnement scolaire.

Mots-clés : Création Théâtrale. Réflexion. Emancipation Intellectuelle. 
A investigação é o resultado de um processo de criação teatral realizado com estudantes do Ensino Médio Integrado, do Instituto Federal de Educação, Ciência e Tecnologia de São Paulo (IFSP), no Câmpus Boituva, no Projeto de Ensino “Jogos Teatrais com Contos na perspectiva filosófica”. Essa ação foi desenvolvida de Agosto de 2016 a Dezembro de 2017, com encontros de duas horas semanais. O grupo foi composto por 18 alunos entre 15 e 17 anos, tendo concluído suas atividades com 8 alunos, dado a extensão do projeto e as dificuldades pessoais encontradas pelos estudantes para participar dos encontros.

O projeto objetivava investigar as possibilidades de criação cênica a partir da utilização de contos que tivessem um viés filosófico. Assim, elegi como primeiro modelo de ação o conto “Bartleby, o escrivão”, de Herman Melville (2005), obra que já havia utilizado com um grupo de licenciandos em Teatro, em outra instituição de ensino. Com o processo, percebemos que o uso de apenas um material possibilitaria um aprofundamento maior nas ações. Passei a apresentar fragmentos do conto, o que gerou muito interesse por parte dos alunos, que tinham que esperar uma semana para saber a sequência da narrativa. A cada fragmento, eu lançava um estímulo diferente para a criação, seguindo as contribuições de Koudela (1999) e Pupo (2005) de “jogos com textos”.

Na abordagem que parte de um texto, Pupo explicita dois caminhos possíveis: no primeiro, parte da análise da narrativa para chegar ao discurso teatral; no segundo, propõe outras formas de apropriação do texto, são eles: O “Recorte e Colagem”, extração de um fragmento de texto, a ser utilizado por um jogador, e que se configura como a única fala possível dentro da improvisação; "Provérbios”, prática a partir de ditados populares; "Motivos”, prática em que se lança o tema ao grupo, que deverá realizar improvisos antes de conhecer o texto original; e “Preenchimento de Elipses”, desenvolvimento das lacunas do texto. Para Pupo (2005, p. 68), “[...] se instala um patamar sólido que permite a descoberta de conotações imprevistas”.

No jogo com a peça didática de Brecht, Koudela (1999, p. 20) se vale de fragmentos da peça didática, os quais servem como modelo de ação no jogo. Vale-se de um procedimento denominado "colado ao texto”, no qual as palavras do texto são mantidas e a improvisação se desenvolve no plano de ações e gestos. Para a autora, instaura-se “[...] um processo interativo entre os participantes do ato artístico o qual revela um novo olhar frente à relações sociais” (p. 19). Isso se deve ao “estranhamento” proposto por Brecht, o qual consiste na "historicização”, ou seja, na representação de "processos e pessoas como históricos, portanto transitórios” (p. 18). 
Elegemos a frase "Preferiria não”, dita várias vezes por Bartleby no conto, como modelo de ação, através da questão: “O que você preferiria não, na escola?”. A pergunta gerou um processo de reflexão do cotidiano escolar, o qual foi revelado nos improvisos que vieram na sequência. Os alunos relataram situações de abuso de poder por parte de professores e gestores, de julgamento por parte dos colegas, além de inquietações em relação à escola e ao futuro profissional.

Houve a apresentação de uma sequência de cenas, no auditório do Câmpus. Professores e alunos debateram os temas que surgiram na criação teatral. Nessa ocasião, os alunos relataram que a metodologia empregada no processo criativo, foi libertadora, e associaram as práticas do Teatro Contemporâneo a práticas mais libertadoras da Educação.

Nesse processo de utilização de situações potentes do cotidiano escolar, foi possível observar o protagonismo dos estudantes e sua emancipação intelectual. Pois, como crê Rancière (2011, p. 11) "Não há ignorante que não saiba uma infinidade de coisas, e é sobre este saber, sobre esta capacidade em ato que todo ensino deve se fundar”.

\section{Referências}

KOUDELA, Ingrid Dormien. Texto e Jogo. São Paulo: Perspectiva, 1999.

MELVILLE, Herman. Bartleby, o escrivão. São Paulo: Cosac Naify, 2005.

OLIVEIRA, Inês Barbosa de; SGARBI, Paulo. Estudos do cotidiano \& Educação. Belo Horizonte: Autêntica Editora, 2008.

PUPO, Maria Lúcia de Souza Barros. Entre o Mediterrâneo e o Atlântico: uma aventura teatral. São Paulo: Perspectiva/CAPES/FAPESP, 2005.

RANCIÈRE, Jacques. O mestre ignorante - cinco lições sobre a emancipação intelectual. 3 ed. Belo Horizonte: Autêntica Editora, 2011. 